\title{
Contract enforcement, capital accumulation, and Argentina's long-run decline
}

\author{
Leandro Prados de la Escosura • \\ Isabel Sanz-Villarroya
}

\begin{abstract}
Argentina has slipped from being among the ten world's richest countries by the eve of World War I to its current position close to mid-range developing countries. Why did Argentina fall behind? We employ a structural model to investigate the extent to which the enforceability of contracts and the security of property rights, as measured by Clague et al.'s "contract intensive money" (CIM), conditioned broad capital accumulation and, subsequently, economic performance in Argentina. Our results suggest that poor contract enforcement played a significant role at the origins of Argentina's unique experience of long-run decline.
\end{abstract}

Keywords Contract intensive money $\cdot$ Economic decline $\cdot$ Argentina

JEL Classification $\quad$ D23 $\cdot$ N16 $\cdot$ N26 $\cdot$ N46 $\cdot$ O43

\section{Introduction}

How has Argentina, a country which occupied a position among the ten richest countries in the world in terms of income per capita in the early twentieth century, slipped to its current place in the ranking, closer to that of Turkey than to Western Europe?

L. Prados de la Escosura $(\square)$

Historia Económica e Instituciones and Instituto Figuerola, Universidad Carlos III de Madrid,

Calle Madrid, 126, Getafe, 28903 Madrid, Spain

e-mail: leandro.prados.delaescosura@uc3m.es

I. Sanz-Villarroya

Estructura Económica, Economía Pública e Historia Económica,

Universidad de Zaragoza, Gran Via 2, Zaragoza, Spain

e-mail: isanzvil@unizar.es 
Argentina began to lose ground when compared with Australia and Canada, countries whose development was also largely due to the exploitation of natural resources and the exports of primary goods, in the late nineteenth century. ${ }^{1}$ However, it was not until the second half of the twentieth century, and in particular during its last quarter, that Argentina fell behind definitively. ${ }^{2}$ Why did Argentine drop back? Why was Argentina not able to catch up with Australia and Canada during the twentieth century? These are questions that still await a definitive answer.

Human and physical capital accumulation remains the key variable for growth (Temple 1999) and its increase depends, ultimately, on the existence of a set of incentives provided by institutions (North 1990, p. 134). Weak capital accumulation, largely attributed to poor institutional quality, has been proposed as a main force in Argentina's falling behind (Taylor 1992, 1998b). In this paper we investigate the extent to which the enforceability of contracts and the security of property rights conditioned broad capital accumulation and, consequently, long-run economic performance in Argentina.

Clague et al. (1999) have suggested a way of measuring compliance with contracts and the security of property rights, "contract intensive money" (CIM), which is defined as the percentage of deposits in money supply (M2). ${ }^{3}$ The idea behind this indicator is that financial assets are held in ways that depend on the definition of property rights. When economic agents operate in a stable context, in which property rights are well defined and guaranteed, it is not risky to keep assets in deposit accounts and, consequently, cash becomes a less attractive option. Therefore the proportion of deposits in the money supply will tend to increase. Ceteris paribus, better contract enforcement will encourage investment and, hence, lead to a higher rate of growth. The opposite situation would pertain in a poorly defined institutional framework. A caveat is, nonetheless, necessary, as already pointed by Clague et al. (1999). In a context of high inflation CIM becomes a defective measure of contract enforcement and, hence, weakens its association/ connection with capital accumulation and, thus, economic growth.

The long-run association between secure contract and property rights, as measured by CIM, broad capital accumulation, and growth in Argentina is investigated with a system of structural equations. Our results suggest that, until the 1960s, poor contract enforcement played a major role in Argentina's unique historical experience of economic decline. Later, between the early 1970s and 1990s, hyperinflation reduced CIMs ability to capture the compliance of contracts. Moreover, it appeared that, it was not just capital accumulation but mainly

\footnotetext{
${ }^{1}$ In other words, before the dates for the beginning of Argentina's retardation (the First World War, the Great Depression and the post-World War II era) suggested, upto now, by economic historians. Cf. Cortés Conde (1997), Di Tella and Zymelman (1967), Díaz Alejandro (1970), Ferrer (1996), Taylor (1992, 1994, 1998b). These results derive from the study of the relative series of GDP per capita between 1875 and 1990 using the unit root method and structural breaks. Cf. Sanz-Villarroya (2004, 2005).

2 See Sanz-Villarroya (2005) and Kydland and Zarazaga (2002).

3 How to measure the connections between institutions, "a construct of the human mind", and investment and growth represents a major challenge. As North, Institutions, p. 107 writes, "We cannot see, feel, touch, or even measure institutions; they are constructs of the human mind". Cf. Knack and Keefer (1995), for an attempt to prove this relationship empirically.
} 
efficiency gains what conditioned Argentina's performance in the late twentieth century (Kydland and Zarazaga 2002).

In the rest of the paper we survey major interpretations of the origins of Argentina's comparative retardation and find that poor institutional quality has been identified as a deterrent for capital accumulation that, in turn, hampered economic growth (Sect. 2). We describe, then, the long-run evolution of CIM in Argentina (Sect. 3); investigate the extent to which CIM conditioned physical and human capital accumulation, hence, growth (Sect. 4) and, lastly, explore how different Argentina's performance might have been if the country's security of contracts and property rights, as proxied by CIM, had been closer to those of Australia and Canada (Sect. 5).

\section{When and why did Argentina begin to decline?}

Argentina, Australia, and Canada are often compared as areas of European settlement, exporters of primary goods under British influence and as case studies that followed similar paths between the end of the nineteenth and the mid-twentieth century. All three were thinly populated, blessed with supplies of natural resources which gave them a privileged position in the international economy despite the fact that they were geographically distant from centers of economic activity (Gallo 1983; Duncan and Fogarty 1984; Platt and Di Tella 1986).

Figure 1 presents Argentina's performance relative to Australia and Canada, in terms of product per person (expressed as its difference in natural logarithms). We have used purchasing power parity adjusted GDP per capita expressed in 1913 US relative prices for the period 1875-1939 and 1980 US relative prices for the period 1940-2001. ${ }^{4}$ Argentina converged towards Australian and Canadian levels but at the turn of the century began to stagnate and decline set in (although occasionally drawing level with Canada until 1930s). A significant, negative structural break took place in 1974 after which Argentina fell further and further behind (Sanz-Villarroya 2005).

A plurality of mostly untested explanations has been proposed for these trends. According to Di Tella and Zymelman (1967), the definitive closing of the frontier was a major difference between Argentina and the other areas of new settlement as no compensatory alternatives emerged. Platt and Di Tella (1985) pointed to the variations in political traditions and the origins of immigrants as the key differential factors while Díaz Alejandro (1985) suggested that a restrictive immigration policy, as followed by Australia, might have encouraged the relative scarcity of labor and

\footnotetext{
${ }^{4}$ The levels of real product per person for 1913 and 1980 are taken from Prados de la Escosura (2000). The volume indices used to project these benchmarks across the entire period are taken from Maddison (2003), except for the period 1875-1935 in Argentina, for which we used Cortés Conde's GDP reconstruction (1997). This procedure attempts to mitigate the index number problem caused by using real product per capita series expressed in relative prices of a distant benchmark year. This is the case with Maddison's World Economy figures in 1990 dollars, which are normally used in this type of comparison. Nevertheless, the use of Maddison's data does not significantly change the results (SanzVillarroya 2005).
} 


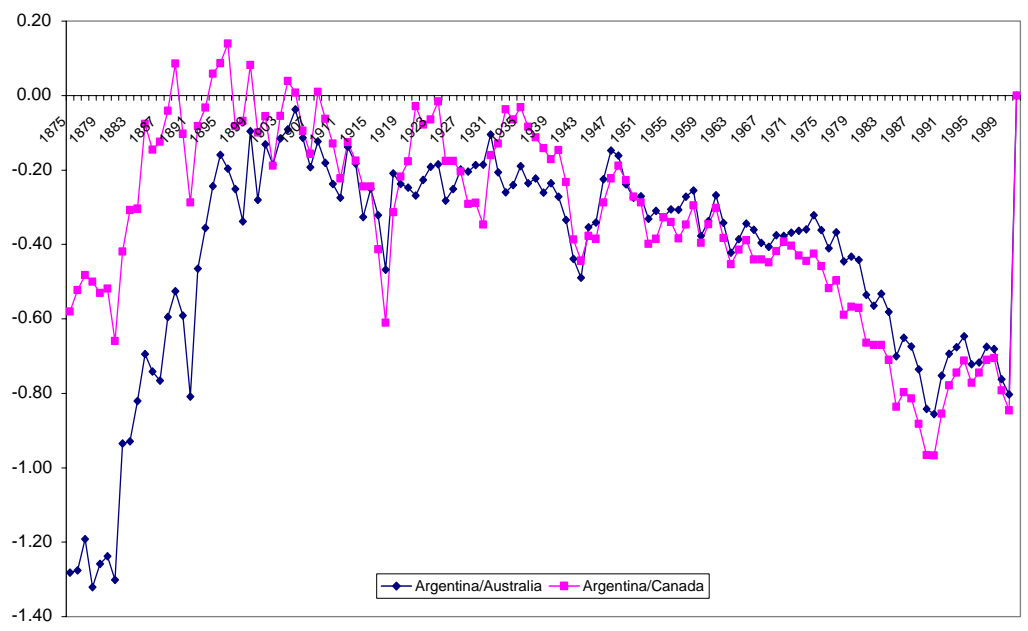

Fig. 1 Argentina's relative GDP per head, 1875-2001 (differences in logs)

increased the productivity of labor. Associated to high immigration is the relatively high dependency rate from which Taylor (1992) infers lower savings rates than in Australia and Canada. In fact, much of the capital entering the country did so as a reaction to such low savings rates (Taylor and Williamson 1994). ${ }^{5}$

Institutions have been recurrently blamed for Argentina's retardation. ${ }^{6}$ For example, Duncan and Fogarty (1984) argued that the contrast between the stable, flexible government of Australia and the bad government of Argentina made for the crucial differences. In Solberg's (1987) influential view, Canadian policy of distributing land among a large number of small farmers was more favorable for growth than the Argentinean allocation which resulted in a small number of landowners with large plots of land and, consequently, a higher wealth inequality. ${ }^{7}$ The erosion of the rule of law since the 1930s, has been pointed out, is at the roots of Argentina's slide from the core to the periphery (Alston and Gallo 2003, 2006; Spiller and Tommasi 2007). Furthermore, from 30s onwards, capital accumulation was hampered by relatively high prices of (mostly imported) capital goods, which was the result of an industrial policy of import substitution (Taylor 1994, 1998a).

\footnotetext{
5 In fact, between 1900 and 1929, Argentina's savings rate was around 10\% lower than that of Australia and Canada and her dependency rate was 5\% higher (Taylor 1992, pp. 922-925). Taylor estimated that, in the long term, around two-thirds of the difference between the savings rates in Argentina and Australia was due to the disparity in their dependency rates.

${ }^{6}$ Cortés Conde (1998b) and Gerchunoff and Fajgelbaum (2006) provide interpretations of Argentine's economic performance in the long-run with special emphasis on the role of institutions.

${ }^{7}$ However, an open land market existed in Argentina where many more immigrants than generally believed became farmers (Sánchez-Alonso 2000). Gallo (1983), argued that lack of capital and agricultural knowledge made advantageous for immigrants to become tenant farmers. Cf. Adelman (1994), for a qualified assessment of Solberg's views. Also, Ferns et al. (1993).
} 
Multiple exchange rates, black markets for foreign currencies, and high customs tariffs induced high relative prices of capital goods (Taylor 1998b; Collins and Williamson 2001) that led to lower capital intensity and reduced productivity growth. After the dramatic decline initiated in 1974 and upto the early 1990s protectionism and high interest rates increased the cost of capital that brought about a reduction in the capital-labor ratio and set in a reallocation of labor towards services (Hopenhayn and Neumeyer 2003).

Thus, poorly defined institutions appear to have constrained capital accumulation and, hence, hindered development in Argentina but establishing how much posits a real challenge. To begin with, quantifying the role of institutions represents a major difficulty. Then, we need to test the extent to which the institutional framework conditions broad capital accumulation and, consequently, economic growth.

In an attempt to define the institutional framework and measure its influence, Clague et al. (1999) proposed an indicator known as CIM which designates the money kept in deposits as a proportion of the money supply:

$$
\mathrm{CIM}=(M 2-C) / M 2
$$

where $C$ is currency outside banks and $M 2$ is the money supply including current and term deposits.

The rationale that lies beneath this indicator is that when economic agents trust that contracts will be respected and do operate in an environment considered to be safe, they hold a larger proportion of their money as deposits, so the CIM indicator tends to increase. CIM measures the proportion of transactions that rely on thirdparty enforcement and, hence, provides an indicator of the security of property rights. ${ }^{8}$ If contracts are enforced, a favorable atmosphere for investment is created and the rate of capital formation tends to rise, leading to economic growth. ${ }^{9}$ In the case of Argentina, the CIM measure, closely associated to economic freedom, political stability, financial development, and inequality, can be interpreted as an indicator of contract enforcement. In Appendix 1 we provide a rigorous econometric testing of the extent to which CIM constitutes a proxy for the security of contracts and property rights. ${ }^{10}$

\footnotetext{
${ }^{8}$ Clague et al. (1999, p. 204), use PCA to show that a group of institutional indicators which includes measures of political and civil freedom, the degree of property rights' definition, and of the frequency of revolutions and coups d'état, has a heavier load in factor 1, while financial development variables appear in factor 2. They, hence, conclude that CIM is mainly a measure of property rights enforcement. Cf. Sylla and Rousseau (2003), for the long-run connections between financial development and growth.

${ }^{9} \mathrm{CIM}$ would weaken as a measure of institutional quality if it were just a measure of savings, so the higher the interest rate, the larger the proportion of the money supply in deposits, and it would not be surprising to find an association between CIM and the rate of investment. We found, however, that CIM is a good predictor of the different components of capital formation that do not necessarily have a high correlation with savings rates and, hence, rejected this scenario for the case of Argentina. To do so, we run regressions for Eq. 2 of Table 2 with farm investment, non-farm investment and government investment instead of total investment rates and the results were highly coincidental with positive and statistically significant associations between CIM and each component of total investment. Data for investment components comes from Della Paolera et al. (2003).

${ }^{10}$ It should be kept in mind, however, that stable institutions can be impediments for growth when under their rule risk taking is constraint and property rights are not enforced (Bueno de Mesquita and Root (2000, p. 7).
} 


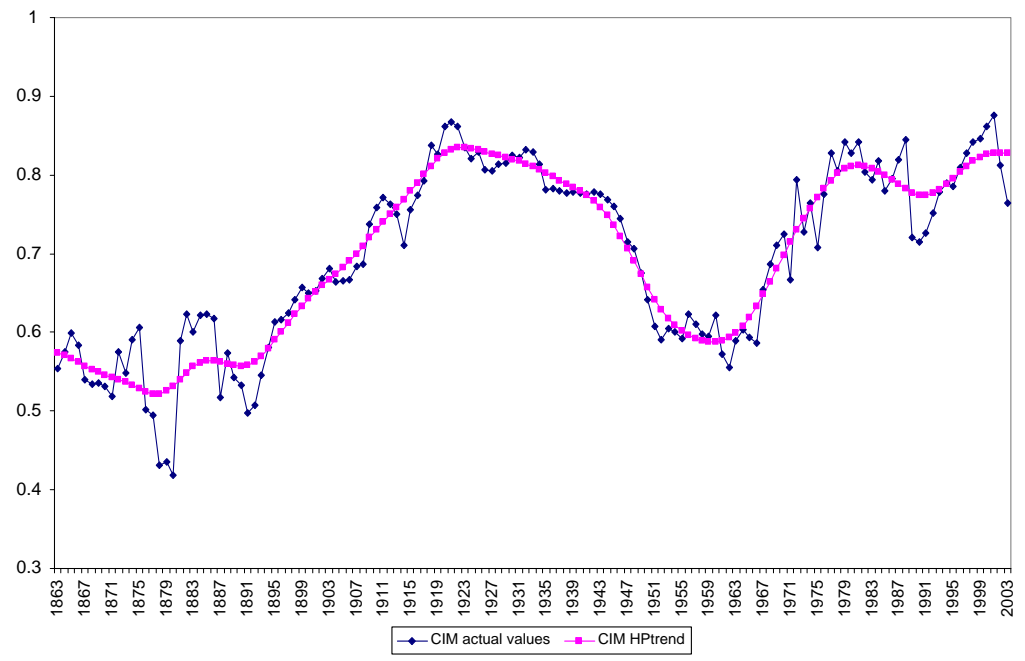

Fig. 2 The evolution of CIM in Argentina, 1863-2003

\section{Trends in CIM}

Distinctive phases or long swings can be established in the evolution of CIM using the deviations from a Hodrick-Prescott trend (Fig. 2). An early period of longterm stability during the late nineteenth century (1863-1891) gave way to a rising trend in the early twentieth century that peaked by 1921 . The third phase or longswing interval, 1922-1960, is one of the long-run decline that started from high levels, relatively stable upto 1931, declined smoothly, first, until 1942, keeping CIM levels above the pre-World War I level up to 1942, and, then, sharply until 1960. The fourth long-swing interval, 1961-1979, corresponds to a recovery of the pre-World War II levels. In the fifth interval, 1980-2003, stability presided over 1974-1988 followed by a sharp decline in 1989. A recovery that peaked in 2001 followed by a sharp contraction characterized the last period. It is worth stressing that the significance of CIM as a measure of contract enforcement and security of property is seriously weakened by high inflation. ${ }^{11}$ Argentina suffered inflationary episodes throughout the second half of the twentieth century and hyperinflation set in between 1971 and 1992. So our measurement of the enforceability of contracts for the late twentieth century is challenged and should be taken with a grain of salt.

The late nineteenth century years were of high political stability and formal democratic institutions that upto 1912 concealed authoritarian Governmental practices. Male universal suffrage was effective since 1853 but had been severely constrained by the requirement of Argentinean citizenship at a time of massive

$\overline{11}$ As Clague et al. (1999, p. 205) stress, "inflation reduces the value of money, raises nominal interest rates, and therefore provides an incentive to shift money from currency and noninterest-bearing accounts into interest-paying time deposits or into foreign currency accounts. This increases CIM". 
immigration. Electoral fraud and lack of political competition showed in the low electoral turnout (Colomer 2004). Nonetheless, political stability and the protection of property rights favored economic progress. CIM expansion was interrupted by cyclical downturns, the most severe one during the Baring crisis. The Baring crisis in the 1890s exposed the conflict between a high fiscal deficit, the impossibility of maintaining a constant exchange rate and a poorly regulated banking system (Della Paolera and Taylor 2001). The lack of co-ordination between monetary and fiscal policy caused the crisis which led to the collapse of the banking system and, thus, to a marked decrease in CIM. ${ }^{12}$

The turn of the century signaled the beginning of a period of economic recovery and political stability which lasted until the First World War and the expansion of CIM peaked in 1921.

Even if a declining trend in CIM initiates in 1922, the highest historical levels of CIM coincide with the period delimited between 1912, when compulsory universal vote for men over 18 years and secret ballot was introduced (Colomer 2004), and the 1930 coup d'etat, in which Argentina enjoyed a transition to an open democracy, an independent judiciary, and a clearer separation of powers (Alston and Gallo 2006). Economic policies maintained orthodoxy until the 1930 s crisis. Free trade policy continued virtually unaltered. ${ }^{13}$ Moreover, between 1890 and 1929 Argentina was anchored to the currency board (Caja de Conversion) with a mission to guarantee the currency's value abroad. ${ }^{14}$

CIM decreased slowly in the years following 1931, although its value remained high for another decade. The beginning of CIM's deterioration coincided with the erosion of judiciary's independence as the 1930 coup d'etat was condoned by the Supreme Court and followed by electoral fraud which paved the way for populism and for a departure from a democratic system with checks and balances. ${ }^{15}$ The fact that the decline in CIM was slow might be associated with changes in macroeconomic policy and with the evolution in the financial development. The public sector implemented a policy of balanced budget after the Depression, which required new sources of income and reductions in spending. ${ }^{16}$ Nevertheless, the change in trade policy would also play its part in the opposite direction. ${ }^{17}$ Exchange

\footnotetext{
12 According to Della Paolera and Taylor (2001, p. 11), the crisis showed initially the symptoms of a traditional banking crisis, that is an increase in the amount of cash in the hands of the public, an increase in the banks' reserves-deposits ratio and the elimination of some financial institutions, which meant the destruction of deposits.

13 In O'Connell's (1986, p. 91) view, there were few changes in trade policy, while the rest of the world returned to protectionism. During 1920s Argentina continued its free trade policy as a producer of staple goods. The main change was a tariff increase in 1923 from 25 to $60 \%$ of the official 'aforo' values. Cf. Di Tella (1986, pp. 122-123).

14 The return to the gold standard took place in 1899 and, despite leaving it again in 1900, 1914, and 1929, the monetary authorities continued to act within its rules (Della Paolera and Taylor 1999).

15 Cf. Iaryczower et al. (2002) and Alston and Gallo (2006). Alston and Gallo emphasize the gap between the conservatives' good economic policies and political short-sightedness during the 1930s.

16 According to Della Paolera and Taylor (1999), the effects of the fiscal decisions taken could have led to contraction until 1935 and it cannot be said that a New Deal type policy was practiced.

17 For Di Tella, the 1930 crisis was the watershed between free trade and protection in Argentina, although the main change came after the Second World War (Di Tella 1986, p. 128).
} 
controls were introduced and the peso was significantly devalued more than once, after the devaluation of the pound in 1931. Quantitative restrictions on imports were also introduced at this time (Alhadeff 1986, p. 104). There inward-looking policies laid the foundations for corporatist policies and populism (Berensztein and Spector 2003, p. 363).

From 1943 onwards, the arrival of military to power and specially the Perón's arrival to power in 1946 and his consecutive terms of office coincide with a fall of CIM to levels similar to those of the last decade of the nineteenth century. The electoral fraud of the 1930s which led to a popular distrust in the rule of law help to explain Juan Domingo Perón's landslide victory following the introduction of male and female universal suffrage in Argentina (Alston and Gallo 2006; Colomer 2004). The impeachment of the Supreme Court, as it represented an obstacle to populist policies, and the introduction of the 1949 Constitution destroyed the separation of powers and implied that property rights were no longer protected through the rule of law (Iaryczower et al. 2002; Alston and Gallo 2006). Early Peronism was a period of macroeconomic shocks during which a strategy of import substitution industrialization was put into practice. Bilateral trade, exchange control, and multiple exchange rates were its most important characteristics (Rock 1987). The increase in the role of government reflected in the increase in state-owned property, interventionism (including control of rents and prices), and higher levels of public spending (Di Tella and Dornbusch 1989). Perón's expansive macroeconomic policy, which aimed at the redistribution of wealth and the increase of spending to finance populist policies, led to inflation. Argentina's inability to return to the rule of law translated into political and economic volatility (high inflation and drastic devaluations) during the decades that followed Perón's arrival to power (Alston and Gallo 2006). ${ }^{18}$

The recovery of CIM in the 1960s coincided with a policy change which included an attempt to face the challenges of inflation, public deficit and foreign debt, as well opening up the economy. ${ }^{19}$

Perón's second term of office was characterized by an expansive monetary policy, which resulted in an uncontrolled rise in the level of inflation. ${ }^{20}$ Hyperinflation, as rightly pointed by Clague at al. (1999), renders CIM useless as a measure of contract enforceability and this explains its rise despite the insecurity of property right faced by economic agents. In fact, hyperinflation and negative real interest rates impeded the financial reform of 1977 to achieve more than a short-

\footnotetext{
18 Institutional instability reveals itself in the shortening of length of Supreme Court justices' tenure (Iaryczower et al. 2002).

19 There were attempts to create an atmosphere which was favorable to private capital by the adoption of measures to stabilize and liberalize the economy under Frondizi's presidency and following an agreement with the IMF. Exchange rates were unified and many controls, both internal and external, were lifted. Under the Onganía dictatorship (1966-1970), a stabilization plan was introduced based on a strict fiscal policy and salary increases which were limited to the previous year's rate of inflation. Exchange controls were also withdrawn at the same time (Di Tella and Dornbusch 1989, pp. 109, 202).

${ }^{20}$ Inflation reached $900 \%$ between 1975 and 1976. Cf. Di Tella and Dornbusch (1989).
} 
lived success, interrupted by the 1980 crisis. ${ }^{21}$ This situation was made worse by the flight of capital, large fiscal and external deficits and, especially, by an enormous foreign debt which would reach record levels in 1982, the year of The Falklands' War (Gerchunoff and Llach 1998, p. 375). In this context of hyperinflation, inequality in income distribution increased (Alvaredo 2006). Attempts to control the hyperinflation and carry out fiscal reform in 1983 and the following years resulted in another failure. This situation would only recover over the 1990s when the Menem government brought the hyperinflation under control, established a fixed rate of exchange and introduced deregulation.

\section{CIM, capital accumulation, and growth}

Once the CIM measure is built and its main trends established, the challenge is to quantify the extent to which it conditioned capital accumulation and, subsequently, economic performance. To provide a response to this question we use a structural growth model based on a system of simultaneous equations designed to avoid problems of endogeneity.

Our starting point is a conventional equation in which the level of real product per head is dependent on GDP per capita in the previous period, on the rate of change of the economically active population (EAP) (as an indicator of the growth of labor), on the average enrollment rate in primary and secondary education (to represent the growth of human capital), on the average rate of investment (as an approximate measure of the growth of physical capital) and, finally, on the rate of variation of the exports ratio to GDP (to indicate how openness changed over time). ${ }^{22}$

We have attempted to endogenize each explanatory variable with supplementary equations (Fig. 3). ${ }^{23}$ For example, the investment rate, one of our main variables, is considered as endogenous in Eq. 2 (Table 2) and its behavior is specified as dependent on the real interest rate, the relative price of capital goods, per capita GDP growth (lagged one period), the variation in the dependency rate and, finally, on CIM. Moreover, we investigate how much does CIM impinge on other variables which are considered endogenous too, such as the EAP variation, education enrollment, and the change in openness.

In the estimation we have employed the seemingly unrelated regression method (SUR) that solves the problem of contemporary correlation between the equations' residuals. The average values of the variables and their standard deviations are shown in Table 1. The econometric results are presented in Table 2. All variables

\footnotetext{
${ }^{21}$ The Central Bank had to take control of 60 institutions in this year (Cf. Gerchunoff and Llach 1998, pp. 358-360).

${ }^{22}$ We have followed Mankiw et al. (1992), approximation in which the level of GDP, instead of its rate of growth, is used as the explanatory variable to test the Solow model. In the Solow model the rate of saving and population growth are considered exogenous and they determine the steady-state level of income per capita.

23 Here we depart from Clague et al. (1999) who run single cross section growth regressions without attempting to endogeneize the independent variables of their growth equation.
} 


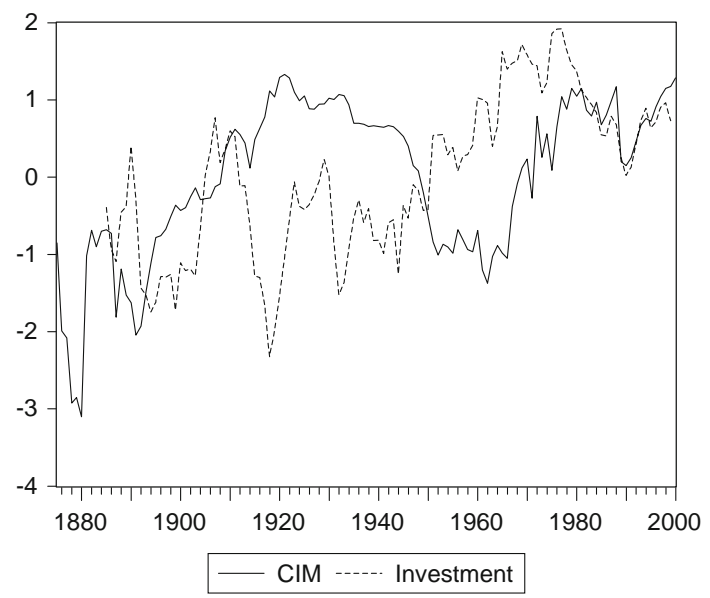

Fig. 3 CIM and the investment rate, 1875-2000 (normalized)

have the expected sign and level of significance. The level of real GDP per head is directly and significantly related to investment and schooling rates and also (though not significantly) to the rate of variation of the EAP. A standard deviation increase in the rate of investment would represent, two periods later, a rise of $1.7 \%$ in per capita GDP; the same increase in the rate of primary and secondary enrollment, six

Table 1 Variables in the models: average and standard deviation

\begin{tabular}{lc}
\hline Variables & Average (standard deviation) \\
\hline Per head GDP level & $8.322(0.544)$ \\
Per capita GDP growth & $0.013(0.072)$ \\
Initial GDP per capita (in logs) & $8.431(0.410)$ \\
Economically active population growth & $0.022(0.019)$ \\
Primary and secondary enrollment(in logs) & $-0.835(0.457)$ \\
Investment rate (in logs) & $-1.976(0.441)$ \\
Real interest rate & $0.061(0.052)$ \\
Dependency rate (rate of variation) & $0.022(0.037)$ \\
Relative price of capital goods (in logs) & $-0.259(0.246)$ \\
CIM (in logs) & $-0.337(0.141)$ \\
RIEF & $-0.108(1.045)$ \\
Openness (rate of variation) & $-0.003(0.151)$ \\
Financial depth (M2/GDP) (in logs) & $-1.101(0.378)$ \\
Terms of trade rate of variation & $0.011(0.106)$ \\
Supreme Court justices' length of tenure (logs) & $1.556(0.690)$ \\
INEQ (inequality) (logs) & $-0.160(0.295)$
\end{tabular}

Sources: Appendix 


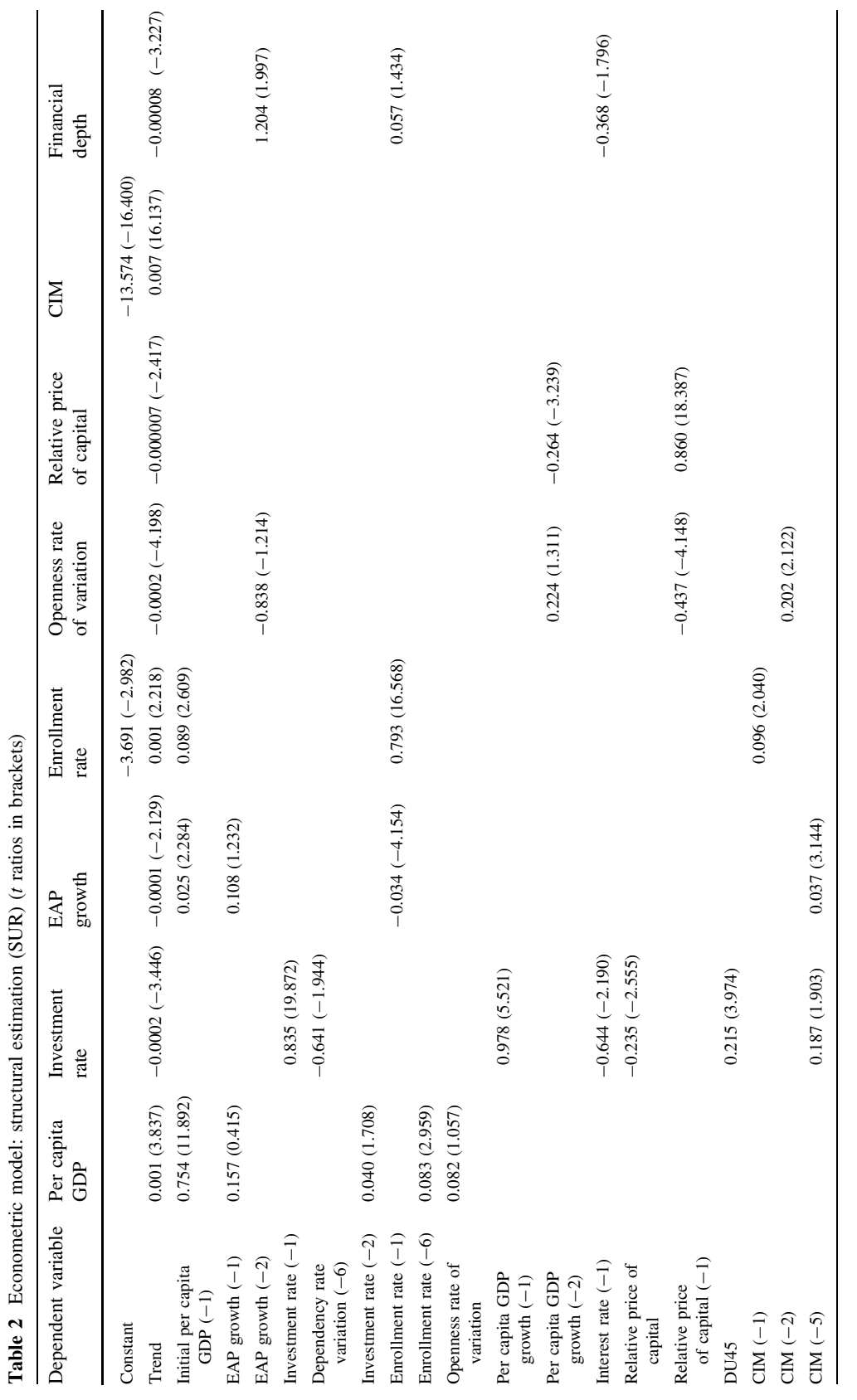




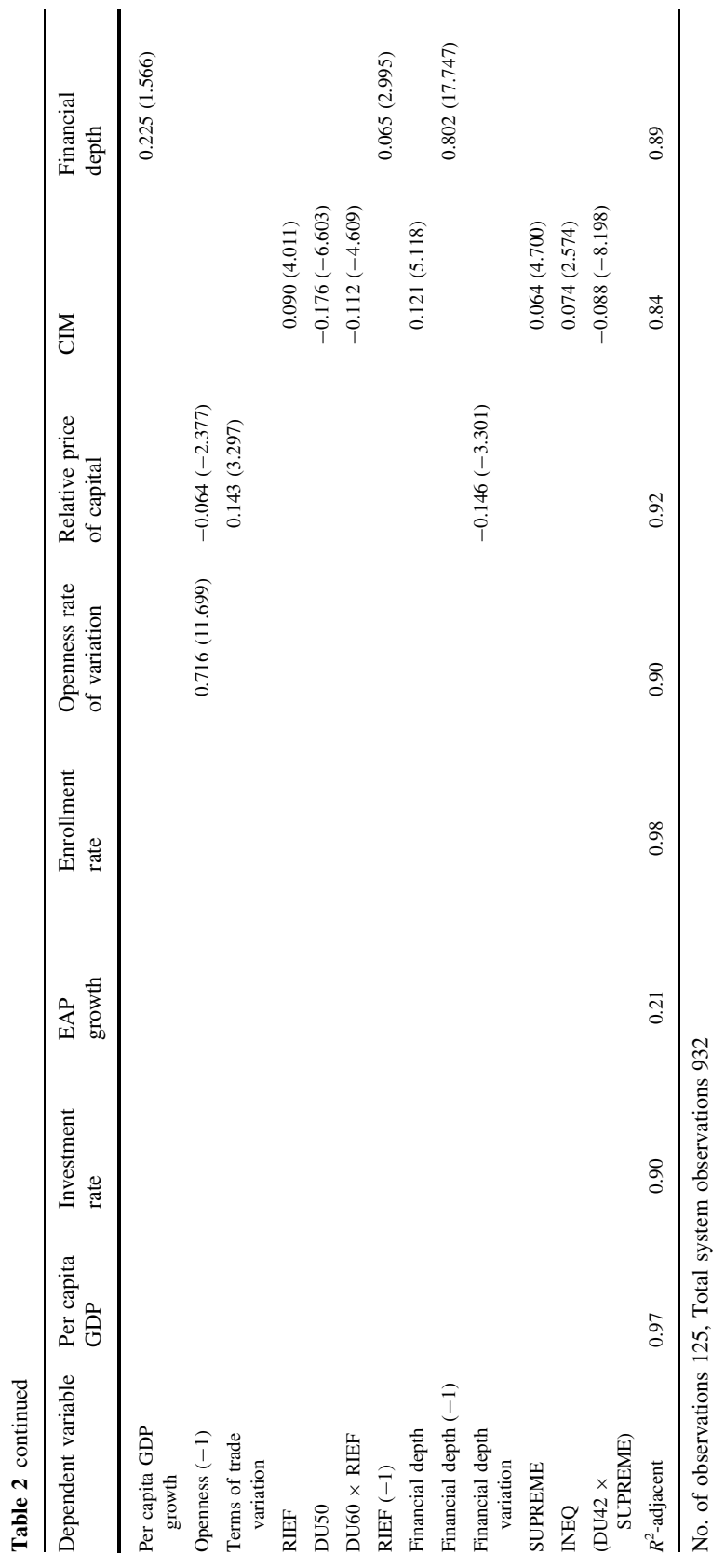


periods later, would raise per capita GDP by $3.8 \%$. From these results we can infer that investment in physical and in human capital lies beneath the evolution of the GDP per head in Argentina. Lastly, an increase of standard deviation in the rate of variation of openness would induce a rise of $1.2 \%$ in the level of income per capita.

It is worth highlighting that the explanatory variables of the level of per capita GDP are influenced by CIM. For example, from Eq. 2 (Table 2) we can conclude that the lower the real interest rate and the relative price of investment goods (in terms of consumer goods), the higher the proportion of GDP dedicated to capital formation in a previous period, while the larger the increase in CIM, the higher the investment rate. In other words, if the real interest rate and the relative price of capital goods decrease by one standard deviation, the rate of investment would rise by 3.3 and $5.8 \%$, respectively. ${ }^{24}$ In turn, one standard deviation increase in the level of CIM five periods earlier would raise the rate of investment by $2.6 \%$. Thus, the improvement in contract enforcement, captured by CIM levels, appears as a major determinant of capital formation in Argentina.

Moreover, these results lend support to the view that attributes the low capital accumulation to a high dependency rate in the 'age of mass migration' and to high relative prices of capital goods since the central decades of the twentieth century. ${ }^{25}$ A standard deviation increase in the variation of the dependency rate means a decrease in the rate of investment of about $2.4 \%$. Additionally, the level of education enrollment, one of the main variables affecting the level of the GDP per head, would increase of about $1.3 \%$ as a consequence of an increase of a standard deviation in CIM. It is also worth mentioning that the more open the economy and the more developed its financial system, the lower the price of capital goods.

All in all, the results of the estimated system of equations suggest that, in Argentina, contract enforcement and the security of property rights, as measured by CIM, would lead to higher rates of human and physical capital accumulation and, thus, in higher per capita GDP.

\section{Concluding remarks: a counterfactual proposition}

So far we have analyzed the causes of Argentina's long-run decline using a structural model which incorporates contract enforcement in the form of the CIM indicator. Our results show that poor compliance with contracts and lack of security in property rights hindered investment in broad capital and, consequently, economic performance (Fig. 4).

A comparison of CIM levels with those of Australia and Canada suggests that economic agents had less confidence in the compliance of contracts in Argentina (Fig. 4). In fact, the average value of CIM for Argentina is 0.70 over 1863-2001, compared with an average of 0.90 and 0.84 for Australia and Canada, respectively.

\footnotetext{
${ }^{24}$ Our results do not support the view that maintains that the relative price of capital goods did not have a clear effect on the demand for investment, as the government could influence it via monetary policy and public investment (Díaz Alejandro 1965, p. 25).

25 Taylor (1994, 1998a). It is worth mentioning that the fact that our results confirm previous ones obtained using independent methods reinforces the robustness of our model.
} 


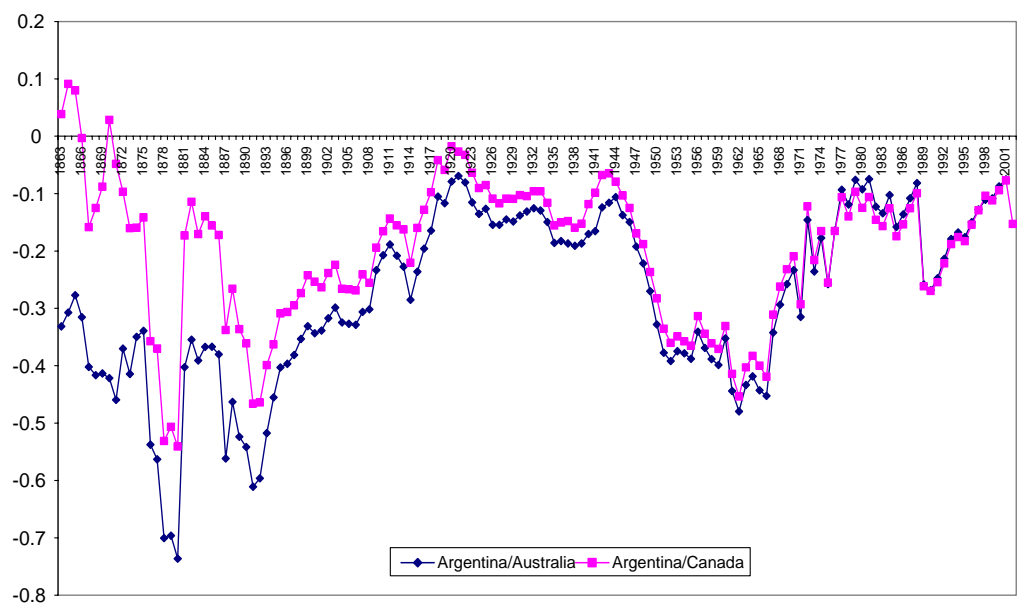

Fig. 4 Argentina's relative CIM, 1863-2002 (differences in logs)

This lower value corresponds to a lower share of investment in GDP, $15.1 \%$ for Argentina, compared with 20.8 for Australia, and 19.4\% for Canada (averages computed for 1885-1998, 1861-2001, and 1870-2001, respectively).

What would have happened if property rights had been better defined and contracts better enforced in Argentina? Would Argentina have caught up with Australia and Canada in terms of material welfare? To provide an answer, we propose a counterfactual exercise which illustrates the contribution of an improvement in CIM to investment and, indirectly, to growth; what would have been the effects on rate of investment and education enrollment and, indirectly, on per capita GDP if Argentina's CIM would have been equivalent to the average of Australia's and Canada's? ${ }^{26}$

The result of this counterfactual exercise indicates that, ceteris paribus, a higher CIM would have led to a higher rate of physical and human capital accumulation (Table 3). The simultaneous rise of the enrollment and investment rates would have increased the pace of economic growth and, thus, reduced the gap in per capita GDP with Australia and Canada (Table 4). Actually, had Argentina reached a CIM similar to the average of Australia's and Canada's, she would have kept pace with Australia until 1960 (Fig. 5a), and though her decline with respect to Canada would have begun in 1940, a substantial deterioration would have not occurred until the 1960s (Fig. 5b).

In this counterfactual scenario, however, even if the investment rate and GDP had been higher (Tables 3,4), a widening gap in per capita income with regard to Australia and Canada would have appeared since the 1960s (Fig. 5a, b). This means that, at least within the framework of our static and partial equilibrium

${ }^{26}$ Note, however, that, as Clague et al. (1999, p. 197) remind us, "cross-country variation in CIM may be idiosyncratic". 
Table 3 Broad capital in Argentina: actual and counterfactual values (\%)

\begin{tabular}{|c|c|c|c|c|c|c|}
\hline & \multicolumn{3}{|c|}{ Investment (\% GDP) } & \multicolumn{3}{|c|}{ Enrollment rate $(\%)$} \\
\hline & \multirow[t]{2}{*}{ Actual } & \multicolumn{2}{|c|}{ Counterfactual (CIM as in) } & \multirow[t]{2}{*}{ Actual } & \multicolumn{2}{|c|}{ Counterfactual (CIM as in) } \\
\hline & & Australia & Canada & & Australia & Canada \\
\hline $1875-1891$ & 11.4 & 13.8 & 12.6 & 14.4 & 16.0 & 15.3 \\
\hline 1892-1921 & 9.4 & 13.7 & 11.7 & 27.0 & 32.6 & 30.8 \\
\hline $1922-1960$ & 12.2 & 19.4 & 17.4 & 44.5 & 49.1 & 47.8 \\
\hline 1961-1979 & 27.1 & 39.9 & 36.9 & 60.5 & 72.6 & 71.2 \\
\hline 1980-2000 & 18.9 & 31.4 & 30.7 & 79.2 & 90.8 & 91.0 \\
\hline
\end{tabular}

Table 4 Argentina's relative per capita GDP: actual and counterfactual values (\%)

\begin{tabular}{llllll}
\hline & \multicolumn{2}{l}{ Australia (100) } & & & \multicolumn{2}{l}{ Canada (100) } \\
\cline { 2 - 3 } \cline { 5 - 6 } & Actual & Counterfactual & & Actual & Counterfactual \\
\hline $1875-1891$ & 40 & 44 & 74 & 80 \\
$1892-1921$ & 80 & 84 & 90 & 91 \\
$1922-1960$ & 77 & 86 & 79 & 86 \\
$1961-1979$ & 69 & 72 & 64 & 67 \\
$1980-2000$ & 51 & 58 & 46 & 52 \\
\hline
\end{tabular}

counterfactual exercise, Argentina's lower CIM does not explain the differences in GDP per head with respect to Australia and Canada during the last four decades of the twentieth century (although, perhaps, in a dynamic general equilibrium framework the results would be more satisfactory). It is true that high inflation weakens significantly CIM as a measure of contract enforcement and security of property during the second half of the twentieth century and, especially, during the hyperinflation years (1971-1991). However, the fact is that other variables such total factor productivity (TFP), perceived as a major determinant of differentials in performance across countries (Prescott 1998), are hardly discussed in the Argentinean literature and, hence, not contemplated here. ${ }^{27}$ Evidence on TFP for Argentina shows a slowdown after 1950 that deepened since the mid-1970s. Thus, TFP growth fell from $2.7 \%$ per year in the 1940 s to $1 \%$ in the $1950 \mathrm{~s}$ and was cut further down to $0.6 \%$ in the 1960 s (Elías 1978, p. 369). Then, it became negative in the $1970 \mathrm{~s}(-0.3 \%)$ and collapsed in the $1980 \mathrm{~s}(-2.1 \%)$ to recover only in the $1990 \mathrm{~s}$ (Kydland and Zarazaga 2002, p. 156).

To sum up, the view that Argentina's long-run decline has deep institutional roots is supported by the evidence provided here. Better contract enforcement and definition of property rights would have promoted broad capital accumulation and, thus, allowed Argentina to keep pace with Australia and Canada until the second

\footnotetext{
27 In fact, Clague et al. (1999, p. 201-202) noticed that most of the impact of CIM is through investment and not through efficiency gains.
} 

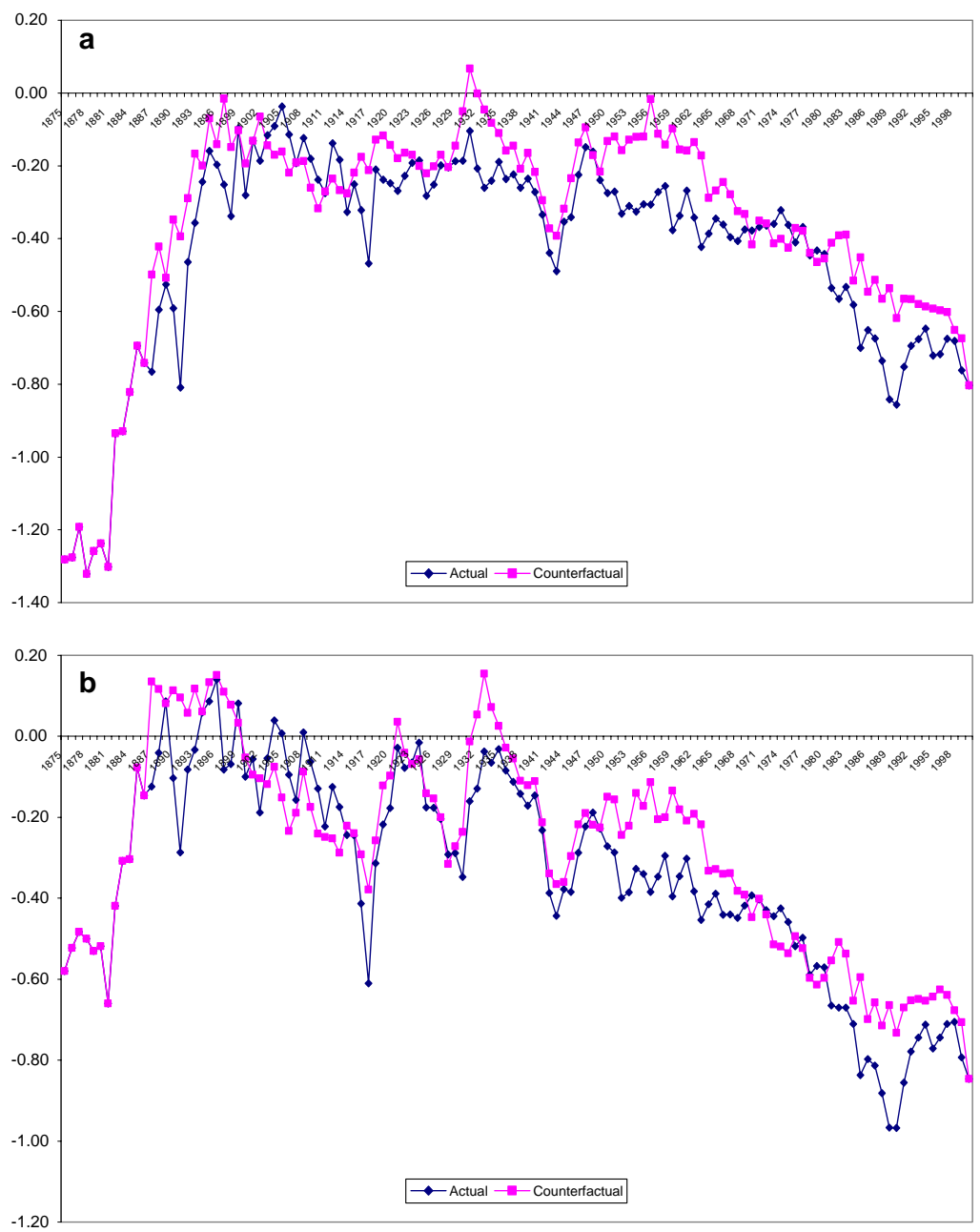

Fig. 5 a Actual and counterfactual Argentina's per capita GDP relative to Australia, 1875-2000 (differences in logs). b Actual and counterfactual Argentina's per capita GDP relative to Canada, 18752000 (differences in logs)

half of the twentieth century. Nonetheless, and at odds with the historical literature, capital accumulation does not seem to suffice for Argentina to maintain its position relative to other countries of new settlement since the 1960s. Her deepening divergence in the late twentieth century seems attributable to a slowdown in TFP growth. The extent to which poor efficiency gains resulted from low quality institutions deserves further research. 
Acknowledgments Earlier versions of this essay were presented at the Columbia University Seminar in Economic History, the 5th World Congress of Cliometrics (Venice 2004), the XIX Jornadas de Historia Económica, San Martín de los Andes (Argentina), the VII Encuentro de Economía Aplicada, Vigo (Spain), and the International Society for New Institutional Economics Conference (Barcelona 2005). We gratefully acknowledge criticism and suggestions by Lee Alston, Samuel Amaral, Albert Carreras, Roberto Cortés Conde, Alan Dye, Michael Edelstein, Andrés Gallo, Pablo Martín Aceña, Patrick O’Brien, Carlos Rodríguez Braun, Albrecht Ritschl, Joan Rosés, Mar Rubio, Blanca Sánchez-Alonso, Richard Sylla, Alan Taylor, Joachim Voth, and Jeffrey Williamson. We alone are responsible for the remaining errors. Pablo Spiller kindly allowed us to use his series of Supreme Court Justices' length of tenure. We acknowledge financial support from Spain's Ministry of Education and Science, research project SEC2002-01596 and Comunidad Autónoma de Madrid, research project CCG06-UC3M/HUM-0872.

\section{Appendix}

\section{Econometric testing of CIM as measure of contract enforcement}

What does CIM depend on? Is it really an institutional indicator? In order to provide a formal answer we have carried out a cointegration analysis between CIM and the variables representing economic freedom (RIEF) — a variable constructed through the principal component analysis, institutional instability-proxied it by the length of tenure of Supreme Court justices (Iaryczower et al. 2002) (Supreme), ${ }^{28}$ income distribution, proxied by the ratio between GDP per worker and the unskilled wage (Prados de la Escosura 2007) $^{29}$ (INEQ), and financial development defined as the ratio of money supply (M2) to GDP (DEPTH). Our quantitative exercise confirms the institutional nature of CIM (Figs. 6, 7, 8, 9).

The objective is to find a stable relationship in the long-run between CIM and each of these variables which will permit us to test for causality, that is, the direction in which those variables are influencing each other. To do so and due to the fact that all these variables are integrated of order one [I(1)], as can be seen in Table 5, we are able to contrast the null hypothesis that there is no cointegration relation between CIM and each of these two variables. The results obtained are presented in Tables 5 and $6 .^{30}$

The fact that a cointegration relationship has been found means that each of these variables has a common trend with CIM and, hence, a stable short-run relationship can be inferred which leads us to develop a Granger causality test between CIM and the rest of the variables. The results presented in Table 6 suggest that RIEF, DEPTH, Supreme, and INEQ are individually causing CIM. Thus, we can conclude that CIM may be consider as a variable that summarizes, and is caused by, variables such as economic freedom, institutional stability, income distribution, and financial development.

In order to explore the kind of association established between CIM and the rest of variables we can now proceed with a cointegration analysis to test the existence

\footnotetext{
${ }^{28}$ Iaryczower et al. (2002) and Alston and Gallo (2003, 2006) support the use of this indicator as a measure of political instability.

29 The rationale for the index is that while the numerator captures returns to all factors of production per worked hour. This inequality index was introduced by Williamson (1997).

${ }^{30}$ Due to space problems we do not present the entirely results here but you can see them in Prados de la Escosura and Sanz-Villarroya (2006).the denominator only encapsulates returns for raw labor, the factor whose ownership is more widespread.
} 


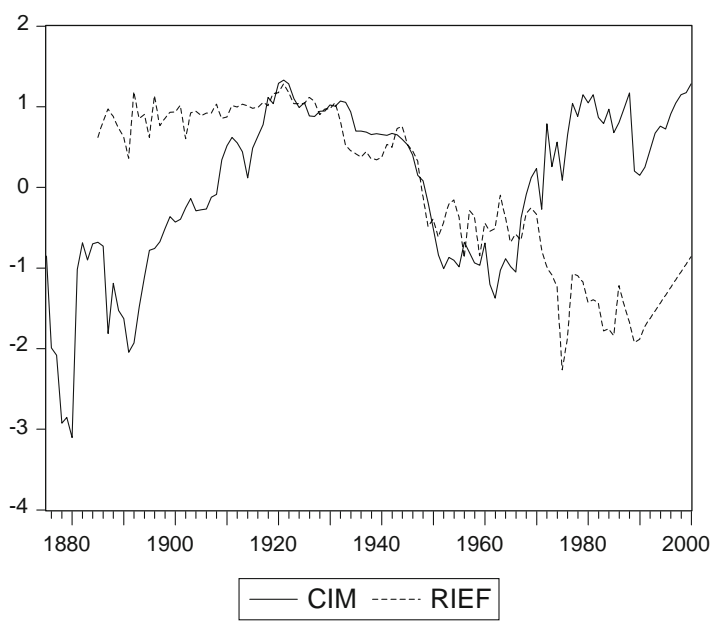

Fig. 6 CIM and RIEF, 1875-2003 (normalized)

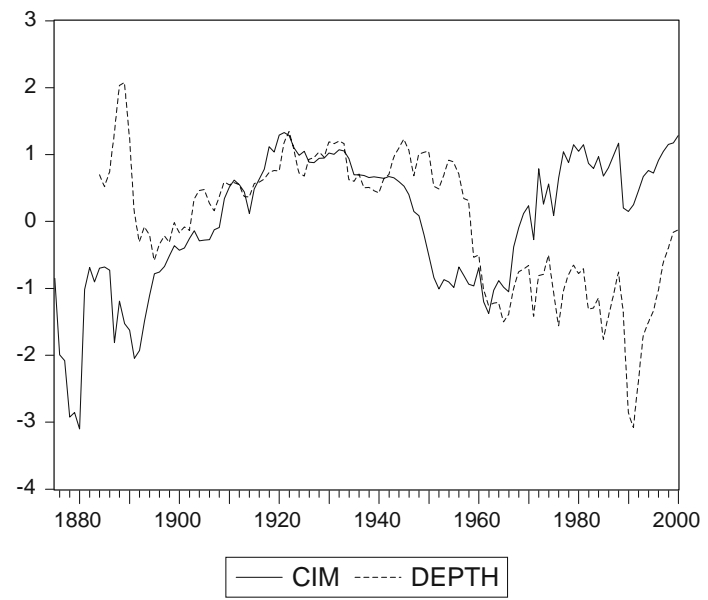

Fig. 7 CIM and financial depth, 1875-2000 (normalized)

of a long-run relationship between CIM, as the dependent variable, and RIEF, DEPTH, Supreme, and INEQ as the explanatory variables so CIM is modelled as an endogenous variable. ${ }^{31}$

\footnotetext{
31 Instead of using extensions of the Gregory and Hansen method for the case of multiple breaks, which would induce us to search for the breaks in an endogenous way again (Bai and Perron 1998) we have accepted the breaks based upon the previous analysis of the individual relationship between CIM and its explanatory variables. Nevertheless, we have chosen the combination of breaks that reports the best adjustment in the model based on the F-statistic and on the AIC selection criteria.
} 


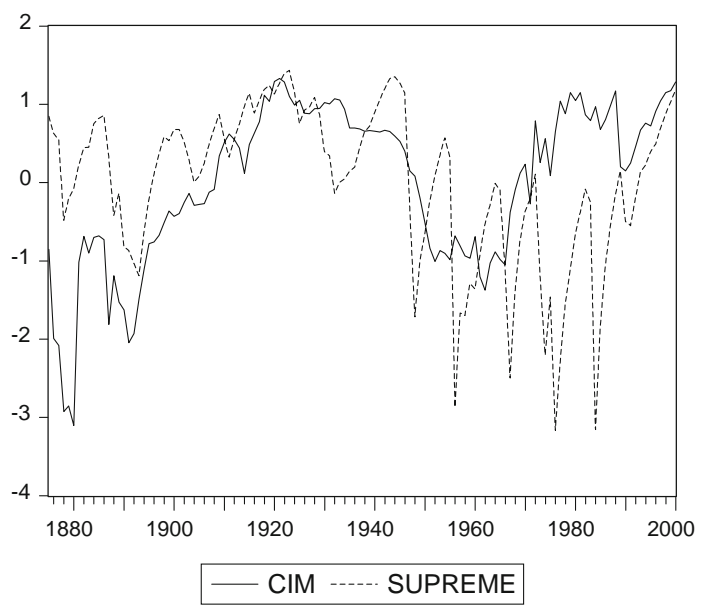

Fig. 8 CIM and the Supreme Court Justices' length of tenure (Supreme), 1875-2000 (normalized)

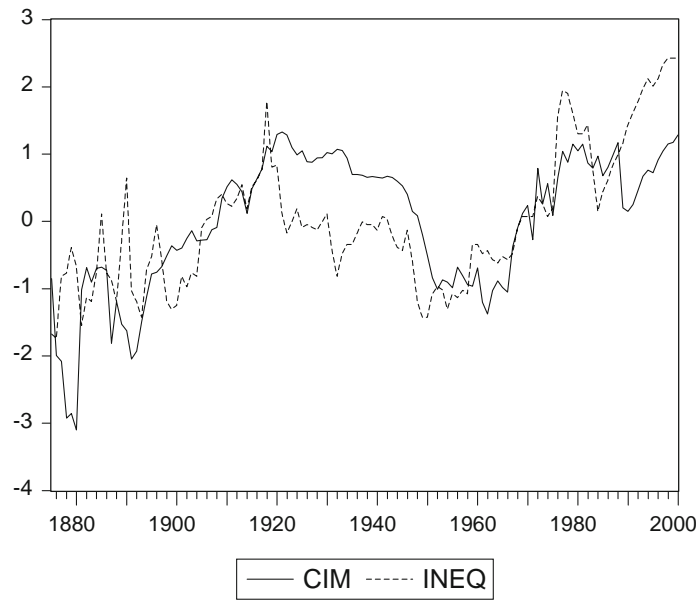

Fig. 9 Evolution of CIM and inequality (INEQ), 1875-2000 (normalized)

The results shown in Table 7 confirm the existence of a cointegration relationship between this set of variables which are the fundamental determinants of CIM's long-run behavior. Furthermore, the sign of this correlation changes from midtwentieth century onwards as the cointegration shifted to a new long-run relationship. A change of regime occurred since 1960 in the long-run relationship between RIEF and CIM and, henceforth, RIEF exhibited a slightly negative relationship with CIM. Thus, a $10 \%$ increase in RIEF would raise CIM by $0.9 \%$ 
Table 5 Individual cointegration models

\begin{tabular}{lllll}
\hline CIM & RIEF & DEPTH & SUPREME & INEQ \\
\hline Break intercept $^{\mathrm{a}}$ & 1960 (negative) & 1946 (negative) & - & - \\
Break regime & 1960 (negative) & - & 1942 (negative) & - \\
ADF test & $-6,112^{\mathrm{b}}$ & $-3,735^{\mathrm{b}}$ & $-4,585^{\mathrm{b}}$ & - \\
\hline
\end{tabular}

The Augmented Dickey-Fuller test (ADF) applied to the residuals from the cointegration relation shown below does not permit us to reject the null hypothesis because the value obtained is smaller than the critical value at $1 \%$ significance

${ }^{a}$ We allow for the existence of a break in the cointegration relation between every pair of variables. Following Gregory-Hansen (2003), if the model is indeed cointegrated with a one-time regime shift in the cointegrating vector, the standard ADF test may not reject the null hypothesis and one could wrongly conclude that there is no long-run relationship. If this is our case, we should be able to find, in a endogenous way, the break which exhibits the minimum value, the maximum value in absolute terms, in an ADF test applied to the residuals from the cointegration relation which contains this particular break. We have to treat the timing of this shift as unknown. The structural change would be reflected in changes in the intercept, regime, and/or in the slope. We have chosen the combination of breaks that reports the best adjustment in the model based on the F-statistic and on the AIC selection criteria (Bai and Perron 1998)

b Rejection at $1 \%$ significance

Table 6 Individual Granger causality test between CIM and the other variables

\begin{tabular}{ll}
\hline $\mathrm{CIM} / \rightarrow$ RIEF & CIM $/ \rightarrow$ DEPTH \\
$\mathrm{RIEF} \rightarrow$ CIM & DEPTH $\rightarrow$ CIM \\
$\mathrm{CIM} / \rightarrow$ SUPREME & CIM $/ \rightarrow$ INEQ \\
$\mathrm{SUPREME} \rightarrow$ CIM & INEQ $\rightarrow$ CIM \\
\hline
\end{tabular}

$I \rightarrow$ means there is no causality in this direction, $\rightarrow$ means there is a significative causality in this direction

before 1960 while, thereafter, a similar increase would reduce CIM by $0.2 \%$. A similar finding is found from 1942 onwards for the long-run relationship between CIM and Supreme. It can be shown, then, that a $10 \%$ increase in Supreme rises CIM by $0.6 \%$ upto 1942 , while reduces it by $0.2 \%$ thereafter. A positive association is found between both DEPTH and INEQ, and CIM. Thus, a 10\% rise in DEPTH would increase CIM by $1.3 \%$, while a similar increase in INEQ leads to a $0.8 \%$ increment in CIM. So, it seems that since 1960 the financial development, DEPTH, and income distribution, INEQ, variables became the main determinants of the positive trend observed in CIM up to the end of the twentieth century, offsetting the decline in economic freedom, RIEF, and in institutional stability, Supreme. ${ }^{32}$ Why income inequality is positively associated to contract enforcement poses? a most challenging question. Is it because since natural resources were the abundant factor

\footnotetext{
32 The tests applied to the long-run relationship between CIM, RIEF, and DEPTH indicates that the determinants of CIM are not redundant as both RIEF and DEPTH have their own particular explanatory power. We are not able to reject the hypothesis that sustains that the errors in the model are homocedastic and independent. Hence, we do not have heteroscedasticity problems and the RESERT test shows that there is no linearity in the parameters and, thus, the linear specification we have proposed appears to be correct.
} 
Table 7 Long-run relationship

\begin{tabular}{lc}
\hline Dependent: LCIM & Parameters \\
\hline Constant & $-13.185(-15.055)$ \\
Time & $0.006(14.814)$ \\
LRIEF & $0.091(3.799)$ \\
LDEPTH & $0.129(5.128)$ \\
LSUPREME & $0.062(4.289)$ \\
LINEQ & $0.084(2.733)$ \\
DU50 & $-0.165(-5.824)$ \\
$($ DU60 $\times$ RIEF) & $-0.113(-4.391)$ \\
$($ DU42 $\times$ LSUPREME) & $-0.086(-7.456)$ \\
\hline
\end{tabular}

$R^{2}$-adjacent $=0.846$, AIC $=-5.709, F=80.471$, No. of observations $=116$

$t$ ratios in brackets, $L$ the variable expressed in logarithms, DU50 dummy variable that represents a change in the level of the long-run relationship after 1950, DU60 and DU42 are dummy variables that represent a change in the relationship of RIEF and SUPREME with CIM, after 1960 and 1942, respectively

Test ADF over the residuals of the model:

Model C, $-6.245^{*}$; Model C/T, $-6.221 *$; Model (none), $-6.272 *$

Test redundant variables (RIEF/LDEPTH):

Ho, the coefficients of the two variables are jointly zero; $F=103.04$ (critical value $=4.79$ ); $\mathrm{Log}$ $\mathrm{LR}=122.44$ (critical value $=10.60)$

Test de White:

Ho, errors are homoscedastic and independents; White test $=12.73$ (critical value $=16.7$ )

RESERT test:

Ho, linear functional form; $F=0.241(0.63)$; $\log \mathrm{LR}=0.256$

Table 8 Error correction model

\begin{tabular}{lc}
\hline Dependent: DCIM & \\
\hline $\mathrm{e}_{t-1}$ & $-0.219(-3.950)$ \\
DRIEF (-2) & $0.021(1.849)$ \\
DDEPTH & $0.199(8.707)$ \\
DDEPTH $(-1)$ & $-0.099(-4.200)$ \\
DSUPREME & $-0.015(-2.207)$ \\
DSUPREME (-2) & $0.012(1.807)$ \\
DLINEQ & $0.100(3.797)$ \\
SEPARATION & $0.008(1.876)$ \\
\hline
\end{tabular}

$R^{2}$-adjacent $=0.496$, AIC $=-4.070, F$-st. $=16.750, \mathrm{DW}=1.987$, No. of observations $=113$

$D$ the variables in differences, $\mathrm{e}_{t-1}$ the lagged error term of the cointegration equation (Table 7) and is the variable that represents the adjustment in the long-run 
in Argentina, openness, associate to growth is, in a Stolper-Samuelson way, also related to inequality? ? $^{33}$

Together with this long-run association we can also derive a short-run relationship, via the error correction model associated with the cointegration relationship. Our results (Table 8) confirm the idea that the variation in CIM is influenced by deviation (in the previous period) from long-run equilibrium, represented by the parameter $\mathrm{e}_{t-1}$.

Moreover, in the short-run, CIM depends on the recent and past variations in RIEF, DEPTH, Supreme, and INEQ. More specifically, the variation of CIM in a particular year would be higher, the larger the change in economic freedom (RIEF) (2 years before), in financial development (DEPTH), in Supreme (2 years before) and the separation of powers variable (Separation). ${ }^{34}$ Additionally, an increase in income inequality (INEQ), leads to a rise in CIM. Conversely, an increase in both Supreme and in DEPTH (a year before) leads to a reduction in the variation of CIM. Thus, in the long-run CIM depends on RIEF, DEPTH, Supreme, and INEQ, a relationship that it is also stable in the short run.

\section{Sources}

\section{Argentina}

Black Market (official-market exchange rate deviation, in logs), 1913-1984, IEERAL (1986); since 1985, Reinhart and Rogoff (2004) data appendix.

Consumption, total and government (ratio to GDP), Della Paolera et al. (2003).

Contract intensive money (CIM) [(M2-C)/M2], 1863-1891, Cortés Conde (1998a); 1892-1948, Della Paolera et al. (2003); since 1948, IMF (2003). Adjusted to IMF levels of M2 and C (currency in circulation).

Dependency rate (percentage of population below 15 and above 64 over population ages 15-64), 1875-1900, Mitchell (1995); since 1900, Astorga et al. (2003).

Depreciation in the real value of money (inflation rate/(100 + inflation rate), Della Paolera et al. (2003).

Economically active population, 1875-1900, Mitchell (1995); since 1900, Astorga et al. (2003).

Financial depth (ratio of money supply, M2 to GDP), M2 as for CIM; GDP at current prices, Della Paolera et al.(2003).

Gross Domestic Product (GDP), at current prices, Della Paolera et al. (2003); at constant prices, 1875-1935, Cortés Conde (1997); since 1935, Maddison (2003).

Interest rate (1875-1893, returns to public bonds; 1913-1933, banking discount rate), 1875-1930, Della Paolera (1994); 1930-1950, Della Paolera y Ortiz (1995);

\footnotetext{
33 Could it be argued that Argentina represents the scenario in which individual savings rates rise with per capita income and, hence, a rise in income inequality increases investment and, thus, growth? As Barro (2000, p.8) points, this hypothesis implies a relatively closed economy to the extent the investment rate is closely related to the savings rate, as it seems to have been the Argentinean case.

34 Separation is a dummy variable that takes value one when there is separation between legislative, executive, and judicial powers and has been computed from Alston and Gallo (2003, Fig. 4).
} 
1950-1973, Vitelli (1990); since 1973, IMF (2003). Real interest rate obtained by adjusting the nominal interest rate by inflation.

INEQ, real income inequality (ratio of real GDP per EAP to real wage rates), real GDP and EAP from the sources quoted above. Real wages from Williamson (1995, updated) and International Labor Office (various years).

Investment rate (investment ratio to GDP), Della Paolera et al. (2003).

Openness (exports ratio to GDP), Della Paolera et al. (2003); since 1985, IMF (2003).

Population, 1875-1900, Mitchell (1995); since 1900, Astorga et al. (2003).

Primary and secondary enrollment (proportion of population ages 5-18 in primary and secondary school), Mitchell (1995); since 1900, Astorga et al. (2003).

Reduced index of economic freedom' (RIEF), is an index whose components are public consumption $(\mathrm{Gi})$ as a proportion of total consumption $[\mathrm{Gi} /(\mathrm{Gi}+\mathrm{Ci})]$, the 'depreciation in the real value of money' (inflation rate/100 + inflation rate), weighted nominal protection (tariff), and the difference (in logs) between the official exchange rate and the market rate ('black market'). The index is derived through the PCA method.

Relative price of capital goods (the investment deflator ratio to the consumption deflator, in logs), Della Paolera et al. (2003).

Separation of powers, a dummy variable that takes value one when there is separation between legislative, executive, and judicial powers, and 0 otherwise, computed from Alston and Gallo (2003), Fig. 4.

Supreme Court justices' length of tenure, number of years, kindly supplied by Pablo Spiller.

Tariff (nominal weighted tariff, i.e., ratio of tariff revenues to imports' values), Della Paolera et al. (2003); since 1985, IMF (2003).

Terms of trade (ratio of export price to import price), Williamson (private communication), 1870-1913; Della Paolera et al. (2003), 1913-1984, since 1984, IMF (2003).

DU45 dummy with values before 1945, 0; otherwise 1. DU507 dummy with values before 1950, 0; 1 otherwise. DU60 dummy with values before 1960, 0;1 otherwise.

\section{Australia}

Contract intensive money (CIM) [(M2-C)/M2], 1863-1948, Vamplew (1987); since 1948, IMF (2003). Adjusted to IMF levels of $M 2$ and $C$ (currency in circulation).

Investment rate (investment ratio to GDP), Vamplew (1987); since 1970, OECD (2004).

\section{Canada}

Contract intensive money (CIM) $[(M 2-C) / M 2], 1863-1948$, Statistics Canada (2004); since 1948, IMF (2003). Adjusted to IMF levels of $M 2$ and $C$ (currency in circulation). 
Investment rate (investment ratio to GDP), 1870-1926, Urquhart (1986); 19261970, statistics Canada (2004); since 1970, OECD (2004).

\section{References}

Adelman J (1994) Frontier development. Land, labour, and capital on the Wheatlands of Argentina and Canada, 1890-1914. Clarendon Press, Oxford

Alhadeff P (1986) Economic controversies. In: Platt DCM, Di Tella G (eds) The political economy of Argentina: 1880-1946, Macmillan/St. Antony's College, London

Alston LJ, Gallo A (2003) The erosion of the rule of law in Argentina 1930-1947. Institute of behavioral sciences, University of Colorado, Boulder

Alston LJ, Gallo A (2006) The erosion of checks and balances in Argentina: an explanation for Argentina's economic slide from the top ten. Institute of behavioral sciences, University of Colorado, Boulder

Alvaredo F (2006) The rich in Argentina over the twentieth century: 1932-2004, MPRA paper no. 650, 2006. http://mpra.ub.uni-muenchen.de/650/

Astorga P, Bergés AR, Fitzgerald EVK (2003) The Oxford Latin American economic history database. The Latin American Centre at Oxford University. http://oxlad.qeh.ox.ac.uk/

Bai J, Perron P (1998) Estimating and testing linear models with multiple structural changes. Econometrica 66:47-78

Barro RJ (2000) Inequality and growth in a panel of countries. J Econ Growth 5:5-32

Berensztein S, Spector H (2003) Business, government, and law. In: Della Paolera G, Taylor A (eds) A new economic history of Argentina, Cambridge University Press, Cambridge, pp 324-368

Bueno De Mesquita B, Root HL (2000) When bad economics is good politics. In: Bueno De Mesquita B, Root HL (Eds) Governing for prosperity. Yale University Press, New Haven, pp 1-16

Clague C, Keefer P, Knack S, Olson M (1999) Contract-intensive money: contract enforcement, property rights, and economic performance. J Econ Growth 4:181-211

Collins WJ, Williamson JG (2001) Capital goods prices and investment, 1870-1950. J Econ Hist 61(1):59-94

Colomer JM (2004) Taming the tiger. Voting rights and political instability in Latin America. Lat Am Polit Soc 46(2):29-58

Cortés Conde R (1997) La economía argentina en el largo plazo (siglos XIX y XX). Editorial Sudamericana, Buenos Aires

Cortés Conde R (1998a) Fiscal crisis and inflation in XIX century Argentina. Documento de Trabajo $\mathrm{n}^{\circ}$ 18, Universidad de San Andrés

Cortés Conde R (1998b) Progreso y declinación de la economía Argentina. Fondo de Cultura Económica, Buenos Aires

Della Paolera G (1994) Experimentos monetarios y bancarios en Argentina: 1861-1930. Revista de Historia Económica 12(3):539-90

Della Paolera G, Ortiz J (1995) Dinero, intermediación financiera y nivel de actividad en 110 años de historia económica argentina. Documentos de Trabajo, Universidad Torcuato Di Tella

Della Paolera G, Taylor AM (1999) Economic recovery from the Argentine great depression: institutions, expectations and the change of macroeconomic regime. J Econ Hist 59(3):567-599

Della Paolera G, Taylor AM (2001) Straining at the anchor. The Argentine Currency Board and the search for macroeconomic stability, 1880-1935. University of Chicago Press, Chicago

Della Paolera G, Taylor AM, Bózolli CG (2003) Historical Statistics. In: Della Paolera G, Taylor AM (eds) A new economic history of Argentina. Cambridge University Press, Cambridge, pp 376-85 (plus CD-Rom)

Díaz Alejandro CF (1965) Precios Relativos y Formación de Capital en la República Argentina. Documento de Trabajo no. 29, Instituto Torcuato Di Tella

Díaz Alejandro CF (1970) Essays in Argentine Economic History. Yale University Press, New Haven

Díaz Alejandro CF (1985) Argentina, Australia and Brazil before 1929. In: Platt DCM, Di Tella G (eds) Argentina, Australia and Canada: studies in comparative development, 1870-1965. Macmillan/St. Antony's College, London, pp 95-109 
Di Tella G (1986) Economic controversies in Argentina from the 1920s to the 1940s. In: Platt DCM, Di Tella G (eds) The political economy of Argentina: 1880-1946. Macmillan/St. Antony's College, London, pp 120-132

Di Tella G, Dornbusch R (1989) The political economy of Argentina, 1946-1983. University of Pittsburgh Press, Pittsburgh

Di Tella G, Zymelman M (1967) Las etapas del desarrollo económico argentino. Editorial Universitaria de Buenos Aires, Buenos Aires

Duncan T, Fogarty J (1984) Australia and Argentina: on parallel paths. Melbourne University Press, Victoria

Elías VJ (1978) Sources of economic growth in Latin American countries. Rev Econ Stat 60(3):362-370

Ferns HS, Gallo E, Watkins M (1993) The prairies and the pampas: a review colloquium. Bus Hist Rev 67:279-299

Ferrer A (1996) La economía argentina. Fondo de Cultura Económica, Buenos Aires

Gallo E (1983) La pampa gringa. La colonización agrícola de Santa Fe, 1870-1879. Editorial Sudamericana, Buenos Aires

Gerchunoff P, Fajgelbaum P (2006) ¿Por qué Argentina no fue Australia? Una hipótesis sobre un cambio de rumbo. Editorial Siglo XXI, Buenos Aires

Gerchunoff P, Llach L (1998) El ciclo de la ilusión y el desencanto: un siglo de políticas económicas argentinas. Editorial Ariel, Buenos Aires

Gregory AW, Hansen BE (2003) Residual-based test for cointegration in models with regime shifts. J Econ 70:99-126

Hopenhayn HA, Neumeyer PA (2003) The Argentine great depression 1975-1990. Universidad di Tella working paper

Iaryczower M, Spiller PT, Tommasi M (2002) Judicial independence in unstable environments, Argentina 1935-1998. Am J Polit Sci 46(4):699-716

International Labor Office (ILO): Statistical yearbooks (various years)

Instituto de Estudios Económicos sobre la Realidad Argentina y Latinoamericana (IEERAL) (1986) Estadísticas de la evolución económica de Argentina 1913-1984. Estudios 9:103-184

International Monetary Fund [IMF] (2003) International financial statistics CD-Rom. International monetary fund, Washington DC

Knack S, Keefer P (1995) Institutions, and economic performance: cross country test using alternative institutional measures. Econ Polit 7:207-227

Kydland FE, Zarazaga C (2002) Argentina's lost decade. Rev Econ Dyn 5(1):152-165

Maddison A (2003) The world economy: historical statistics. OECD, Paris

Mankiw NG, Romer D, Weil DN (1992) A contribution to the empirics of economic growth. Q J Econ 107(2):407-437

Mitchell BR (1995) International historical statistics. The Americas, 1750-1988. Stockton Press, New York

North DC (1990) Institutions, institutional change and economic performance. Cambridge University Press, Cambridge

O'Connell A (1986) Free trade in one country: the case of Argentina in the 20s. In: Platt DCM, Di Tella G (eds) The political economy of Argentina: 1880-1946. Macmillan/St. Antony's College, London

OECD (2004) OECD National Accounts. OECD, Geneva, http://www.oecd.org/

Platt DCM, Di Tella G (1985) Argentina, Australia and Canada: studies in comparative development, 1870-1965. Macmillan/St. Antony's College, London

Platt DCM, Di Tella G (1986) The political economy of Argentina: 1880-1946. Macmillan/St. Antony's College, London

Prados de la Escosura L (2000) International comparisons of real product, 1820-1990: an alternative data set. Explor Econ Hist 37(1):1-41

Prados de la Escosura L (2007) Inequality and poverty in Latin America. A long-run exploration. In: Hatton TJ, O'Rourke KH, Taylor AM (eds) The new comparative economic history. MIT Press, Cambridge, pp 291-315

Prados de la Escosura L, Sanz-Villarroya I (2006) Contract enforcement and Argentina's long-run decline, Universidad Carlos III de Madrid Working Papers in Economic History 06-03, 2006

Prescott EC (1998) Needed: a theory of total factor productivity. Int Econ Rev 39(3):528-552

Reinhart C, Rogoff KS (2004) The modern history of exchange rate arrangements: a reinterpretation. Q J Econ 119(1):1-48 
Rock D (1987) Argentina 1516-1987. From Spanish colonization to Raúl Alfonsín. University of California Press, Berkeley

Sánchez-Alonso B (2000) Those who left and those who stayed behind: explaining emigration from the regions of Spain, 1880-1914. J Econ Hist 60(3):730-755

Sanz-Villarroya I (2004) Las tendencias a largo plazo de la economía argentina: 1875-2000. Revista de Historia Económica 22(1):177-205

Sanz-Villarroya I (2005) The convergence process of Argentina with Australia and Canada: 1875-2000. Explor Econ Hist 42:439-458

Solberg CE (1987) The prairies and the pampas: Agrarian policy in Canada and Argentina: 1880-1930. Stanford University Press, Stanford

Spiller P, Tommasi M (2007) The institutional foundations of public policy in Argentina. Cambridge University Press, New York

Statistics Canada: historical statistics of Canada, 2004. http://www.statcan.ca/

Sylla R, Rousseau P (2003) Financial systems, economic growth, and globalization. In: Bordo MD, Taylor AM, Williamson JG (eds) Globalization in historical perspective. University of Chicago Press, Chicago, pp 373-413

Taylor AM (1992) External dependence, demographic burdens and Argentine economic decline after the Belle Époque. J Econ Hist 52(4):907-936

Taylor AM (1994) Tres fases del crecimiento económico argentino. Revista de Historia Económica 12(3):649-683

Taylor AM (1998a) Argentina in the world capital market: saving, investment and the international capital mobility in the twentieth century. J Dev Econ 57(1):147-184

Taylor AM (1998b) On the cost of inward-looking development: price distortions, growth and divergence in Latin America. J Econ Hist 58(1):1-19

Taylor AM, Williamson JG (1994) Capital flows to the new world as an intergenerational transfer. J Polit Econ 102(2):348-371

Temple J (1999) The new growth evidence. J Econ Lit 37(1):112-156

Urquhart MC (1986) New estimates of gross national product, Canada, 1870-1926: some implications for Canadian development. In: Engerman SL, Gallman RE (eds) Long-term factors in American economic growth, NBER studies in income and wealth, 51. University of Chicago Press, Chicago, pp 9-94

Vamplew W (1987) Australians: historical statistics. Fairfax, Syme and Weldon, Canberra

Vitelli G (1990) Las lógicas de la economía argentina: inflación y crecimiento. Prendergast, Buenos Aires

Williamson JG (1995) The evolution of global markets since 1830: background evidence and hypotheses. Explor Econ Hist 32(1):141-196 (updated)

Williamson JG (1997) Globalization and inequality, past and present. World Bank Res Obs 12(2):117135 